\title{
Marketing Public Relation Peremajaan Merek sebagai Strategi Pemasaran dalam Membangun Citra Produk Baru
}

\author{
Irene Melia Puspita ${ }^{1^{*}}$ \\ ${ }^{1}$ London School of Public Relations Jakarta \\ Jl. KH Mas Mansyur Kav. No. 35, Jakarta Pusat - Indonesia \\ *Email korespondensi: irenemelia96@gmail.com
}

\begin{abstract}
Brand image takes an important role in business objectives. Two years ago, Sour Sally rejuvenated (rebranding) to build their image into a healthy and tasty dessert and targeted bigger market. This is because Sour Sally a dessert for women market segment has a girlie image that caused stagnant sales. This blurred image became an obstacle for Sour Sally to sell their products. Therefore, Marketing Public Relations has an important role to build the image of All New Sour Sally. This research uses the theory of Marketing Public Relations and Image and uses descriptive qualitative through interview as primary data. This study discusses the main tools of Marketing Public Relations according to Kotler \& Keller. In order to build Sour Sally image, marketing communications division use Marketing Public Relations tools such as publications, events, sponsors, news, speeches, community service activities, and media identity. The result indicates digital publication and social media and events are the most commonly used to communicate All New Sour Sally.
\end{abstract}

Keywords: Marketing, Public relations, Rejuvenate, Brand, Images

\begin{abstract}
Abstrak
Citra merek mengambil peran penting dalam tujuan bisnis. Dua tahun lalu, pioneer frozen yogurt di Indonesia, Sour Sally, melakukan peremajaan merek (rejuvenation) untuk membangun citra baru Sour Sally. Hal ini karena Citra feminisme menjadi kendala bagi Sour Sally dalam memasarkan produk. Marketing Public Relations memiliki peran penting untuk membangun citra Sour Sally yang baru. Penelitian ini menggunakan teori Pemasaran Hubungan Masyarakat dan Citra. Penelitian ini dilakukan dengan pendekatan deskriptif kualitatif. Data primer diperoleh melalui wawancara, studi kepustakaan, sedangkan data sekunder diperileh dari internet. Penelitian ini membahas Pemasaran Hubungan Masyarakat menurut Kotler \& Keller. Divisi komunikasi pemasaran menggunakan alat-alat Pemasaran Hubungan Masyarakat seperti publikasi, acara, sponsor, berita, pidato, kegiatan pelayanan masyarakat, dan media identitas. Hasil penelitian ini adalah: publikasi digital, media social, dan penyelenggaraan acara, paling sering digunakan untuk berkomunikasi membangun citra Sour Sally yang baru.
\end{abstract}

Kata kunci: Pemasaran, Hubungan masyarakat, Peremajaan, Merek, Citra

\section{PENDAHULUAN}

Citra yang dibentuk sebuah perusahaan merupakan elemen esensial untuk mempengaruhi kesuksesan sebuah brand. Sebuah profit-organization company selalu ingin mempunyai citra brand positif sehingga mereka mendukung Marketing Public Relations (Thomas L. Harris, 1991). Marketing Public Relations merupakan proses merencanakan, melakukan dan mengevaluasi kegiatan untuk meningkatkan penjualan dan kepuasan pelanggan. Kegiatan itu dilakukan dengan membuat strategi komunikasi untuk menyampaikan informasi yang kredibel.

Salah satu perusahaan bisnis yang melakukan fungsi Marketing Public Relations adalah Sour Sally, brand frozen yoghurt pertama di Indonesia yang berdiri tahun 2008. Outlet Sour Sally tersebar di Jakarta, Bandung, Medan, Surabaya, Palembang, Bali, Balikpapan, Malang, Samarinda, Makassar, Semarang. Di tanah air, frozen yoghurt bukan suatu yang baru. Artikel The New Kontan Weekend (2010), menyebut selama 2010-2012, setidaknya tercatat lebih dari 75 brand frozen yoghurt di Indonesia.

Banyaknya brand frozen yoghurt membuat persaingan yang ketat di antara para pemegang merek. Oleh sebab itu, untuk mempertahankan eksistensi brand di tengah persaingan pasar tersebut, 
p-ISSN: 0853-4470 - Vol. 02, No. 01 (2019), pp. 19-26

para pemegang merek melalukan berbagai upaya. Salah satu merek yang berupaya tersebut adalah Sour Sally.

Pada 2015, Sour Sally melakukan transformasi, melalui program rejuvenation "All New Sour Sally”. Hal itu ditempuh karena pada mulanya Sour Sally mengalami kesulitan memasarkan produk karena target market yang sempit. Pada saat itu, penetapan target market remaja perempuan, membentuk citra Sour Sally "girlie" sehingga terbentuk persepsi bahwa frozen yoghurt dikonsumsi oleh remaja perempuan saja. Padahal minuman itu dapat dikonsumsi semua gender untuk hidup sehat.

Sour Sally ingin memperluas target marketnya hingga usia 21 tahun ke atas dengan lingkup wanita karir, eksekutif muda, keluarga berdasarkan consumer interest seperti menyukai fashion, kuliner, dan musik. Sour Sally juga ingin menghilangkan citra girlie dan berupaya membangun pesan healthy lifestyle dengan produk dessert yang enak dan sehat.

Dalam kaitan itulah penelitian ini dilakukan yakni untuk melihat kepuasan konsumen, melalui rejuvenation Sour Sally yang dalam memasarkan produknya pastinya tidak lepas dari campur tangan Marketing Public Relations.

Adapun rumusan masalahnya adalah: (1) Bagaimana strategi Marketing Public Relations PT. Berjaya Sally Ceria melalui rejuvenation dalam membangun konsep baru All New Sour Sally; (2) Bagaimana dampak implementasi dari strategi Marketing Public Relations yang dilakukan oleh Sour Sally; (3) Kendala apa saja yang dihadapi oleh Marketing Public Relations Sour Sally saat melakukan rejuvenation?

\section{KERANGKA TEORI \\ 1. Marketing Public Relations}

Marketing Public Relatian menurut Thomas L. Harris (dalam Ruslan, 2016) adalah proses merencanakan, melakukan dan mengevaluasi kegiatan yang dapat meningkatkan penjualan dan kepuasan pelanggan dengan cara membuat strategi komunikasi untuk menyampaikan informasi yang kredibel. Philip Kotler dikutip Ruslan (2016) mengatakan Marketing Public Relations dapat bekerja untuk menambah nilai suatu produk lewat kemampuannya untuk menghasilkan pesan yang kredibel bagi konsumen.

Pengembangan konsep Marketing mengacu kepada Customer-Oriented, Relationship Customer \& Marketing. Philip Kotlerlah yang pertama kali memunculkan konsep Mega Marketing, perpaduan antara kekuatan Public Relations dan Marketing Mix. Kemudian munculah istilah Marketing Public Relations (MPR), sebagai pengembangan dari Mega Marketing yang dipopulerkan oleh Thomas L. Harris (Ruslan, 2016: 243).

Hasil penelitian Lembaga The Golin tentang MPR menyebutkan MPR dapat membangun kesadaran dan pengetahuan brand terutama pada pengenalan produk. MPR dinilai efektif dalam meningkatkan penjualan sebab MPR lebih efektif daripada iklan. Selain itu banyak perusahaan menggunakan konsultan PR dalam kegiatan MPR (Ardianto, 2016: 272).

Menurut Ardianto (2016), konsep Marketing Public Relations dapat dikatagorikan dalam tiga taktik MPR (Three Ways Strategy) yaitu: (1) Pull Strategy, yakni upaya menyelenggarakan komunikasi timbal balik dua arah yang dilandasi oleh pesan dan informasi yang dapat dipercaya. Dengan begitu, diharapkan tercipta kesan positif terhadap lembaga yang diwakilinya; (2) Push Strategy (mendorong pemasaran). Push Strategy merupakan upaya untuk merangsang pembelian dan memberikan nilai-nilai (added value) atau kepuasan bagi pelanggan yang telah menggunakan atau mengkonsumsi produk; (3) Pass Strategy (mempengaruhi atau menciptakan opini publik yang menguntungkan). Pass Strategy merupakan upaya untuk menciptakan citra publik yang ditimbulkan melalui kepedulian terhadap masalah-masalah yang berkaitan dengan sosial dan lingkungan hidup.

Pengembangan konsep Marketing Public Relations dianggap cukup efektif dan efisien sebagai jalur komunikasi penyebaran pesan. Selain itu, MPR juga memiliki kekuatan untuk membujuk (persuasive approach) dan mendidik (educated) konsumennya (Ruslan, 2016: 251) Selain itu sebagaimana disampaikan Philip Kotler dan Kevin Lane Keller (2009), tujuan dari MPR adalah: (1) membangun kesadaran dengan menempatkan cerita di media untuk membawa perhatian kepada produk, jasa, orang, organisasi atau ide: (2) membangun kredibilitas melalui pesan dalam konteks 
p-ISSN: 0853-4470 - Vol. 02, No. 01 (2019), pp. 19-26 editorial; (3) membantu mendorong antusiasme wiraniaga dan penyalur dengan cerita-cerita tentang produk baru sebelum produk tersebut diluncurkan; (4) menurunkan biaya promosi karena biaya MPR lebih kecil daripada iklan media.

Menurut Ruslan (2016: 252), Marketing Public Relations dibutuhkan karena: (1) meningkatnya biaya promosi yang tidak seimbang dengan keuntungan yang diperoleh; (2) persaingan promosi dan publikasi yang ketat di media elektronik, media cetak dan media lainnya; (3) selera konsumen yang berubah (tidak loyal) karena banyaknya pilihan produk yang ditawarkan; (4) turunnya perhatian atau minat konsumen terhadap tayangan iklan, karena pesan iklan cenderung berlebihan dan membosankan bagi konsumennya.

Sementara itu alat-alat Marketing Public Relations menurut Kotler dan Keller (2009) adalah: (1) publikasi, dapat berupa kegiatan komunikasi untuk mempengaruhi pasar sasaran mencakup laporan tahunan, brosur, artikel, materi audio visual, majalah perusahaan dan newsletter perusahaan; (2) acara, berupaya konferensi, seminar, outing (tamasya), trade shows (pemajangan produk), pameran dagang, kompetisi, acara ulang tahun yang dapat menarik public; (3) pemberian sponsor, sekaligus mempromosikan merek dan nama perusahaan yang dilakukan dalam bantuk memberi donasi pada acara pertandingan olahraga, acara budaya, acara amal.

Selain itu ada juga kegiatan dalam bentuk membuat berita yang merupakan tugas utama professional tenaga humas yaitu menemukan atau menciptakan berita yang menyenangkan mengenai perusahaan, produk, maupun lingkungannya. Kemudian mengadakan kegiatan Layanan Masyarakat untuik membangun itikad baik melalui pemberian sumbangan, kontribusi waktu untuk aksi sosial untuk masyarakat.

Pidato juga dapat dilakukan untuk mengisi berbagai acara pada berbagai jenis kegiatan, serta membuat Media Identitas. Perusahaan memerlukan identitas visual yang dikenali dengan cepat. Identitas Visual perusahan dapat berupa logo perusahaan, brosur, tanda pengenal, kartu bisnis, bangunan, seragam, cara berpakaian, dan lainnya.

\section{Citra}

Setiap perusahaan perlu membangun citra untuk memberikan keuntungan kepada perusahaan. Citra menurut Bill Canton (dalam Soemirat \& Ardianto, 2016: 334) adalah perasaan atau gambaran diri publik terhadap perusahaan, kesan yang sengaja diciptakan dari suatu obyek, orang atau organisasi. Winangsih Syam (dalam Ardianto E, 2014: 98) menyebut citra merupakan hasil dari sejarah atau pengalaman citra tersebut.

Beberapa hal yang membentuk citra (Ishaq, 2017) adalahL (1) Identitas. Identitas dibagi menjadi, identitas fisik yaitu nama, motto, tag line, logo, akronim, pilihan font, warna, sibol, instrumen atau lagu, jingle. Adapun identitas non-fisik adalah filosofi, sejarah, nilai, budaya, kepercayaan, yang biasanya disematkan dalam identas fisik; (2) Manajemen Organisasi. Berkaitan dengan visi, misi, sistem pengambilan keputusan, struktur organisasi, sistem pelayanan, positioning organisasi dan sebagainya; (3) Pola Komunikasi. Setiap organisasi/perusahaan akan menerapkan pola komunikasi yang berbeda-beda (internal maupun eksternal); (4) Kualitas Produk. Kualitas produk dan layanan organisasi atau perusahaan sangat tergantung pada segmentasi organisasi. Karakter produk ini menjadi salah satu faktor pembentuk citra suatu organisasi atau perusahaan.

Sementara itu, jenis citra menurut Jefkins (2002: 20) meliputi (1) Citra Bayangan. Citra ini membahas anggapan pihak luar tentang organisasi/perusahaan; (2) Citra yang berlaku, merupakan kebalikan dari Citra Bayangan yakni citra yang diperoleh pihak luar mengenai suatu oganisasi; (3) Citra yang Diharapkan, suatu citra keinginan yang ingin dicapai oleh pihak manajemen; (4) Citra Perusahaan, berkaitan dengan citra organisasi secara keseluruhan; (5) Citra Majemuk, merupakan pelengkap dari Citra Perusahaan.

\section{Rejuvenation (Rebranding)}

Menurut Okezone (2011), sebuah brand dapat mengalami penuaan karena perkembangan zaman. Rejuvenation dapat dilakukan secara berkala sesuai dengan kebutuhan. Biasanya, ketika 
brand sudah mulai diabaikan, maka penjualan mulai berkurang, dan dalam fase stagnan hal itu membutuhkan peremajaan merek (Batey, 2016).

Selain itu, rejuvenation dapat terjadi karena: (1) adanya perkembangan kompetitor sehingga perubahan target pelanggan; (2) semakin banyak pesaing baru yang masuk dengan visualisasi yang lebih muda; (3) Melindungi brand tersebut dengan menambahkan atau menciptakan nilai tambah yang baru yang lebih relevan dengan keadaan pasar saat ini (Okezone, 2011).

\section{METODE PENELITIAN}

Penelitian ini menggunakan pendekatan penelitian kualitatif. Penelitian ini berhubungan dengan pengalaman, persepsi, ide menurut pandangan narasumber terutama mengkaji strategi Marketing Public Relations dan tidak mengukurnya dengan angka.

Paradigma penelitian yang digunakan adalah paradigma konstruktivisme, dan peneliti bertujuan untuk membangun pemahaman dalam mendeskripsikan pengalamannya berdasarkan apa yang diteliti. Untuk itu ada dua informan yang diwawancarai yakni Brand Manager Sour Sally, dan Assistant Brand Manager Sour Sally dari kalangan internal. Informan ekternal meliputi Customer Sour Sally yang berusia 18-25 tahun (target market Sour Sally baru) dan berdomisili di Jakarta. Mereka dipilih karena mengetahui dan mengikuti perkembangan Sour Sally, serta telah mengonsumsi Sour Sally selama minimal dua tahun.

Folus penelitian adalah strategi Marketing Public Relations menurut Kotler dan Keller (2009) yaitu publikasi, acara, pemberian sponsor, berita, kegiatan layanan masyarakat, pidato dan media identitas.

Data diperoleh melalui wawancara, survei/kuensioner (angket). Peneliti menggunakan wawancara semi terstruktur, dengan menyiapkan daftar pertanyaan yang dapat dikembangkan sesuai kebutuhan. Selain itu, peneliti menggunakan observasi partisipan, dokumentasi dan survei.

Peneliti menggunakan data sekunder yaitu riset perpustakaan, data perusahaan, media elektronik.

Peneliti menggunakan teknik analisis Model Miles dan Huberman yaitu aktivitas analisis data kualitatif diakukan secara interaktif dan berlangsung secara terus menerus sampai tuntas, sehingga datanya sudah jenuh lalu dibagi dalam tiga proses, reduksi data,model data dan penarikan kesimpulan. (Sugiyono, 2010: 91-99)

Dalam penelitian ini, peneliti menggunakan teknik trianguasi sumber dengan mengecek data yang diperoleh melalui tiga atau lebih sumber. Peneliti memilih narasumber yang terpecaya.

\section{HASIL PENELITIAN}

PT. Berjaya Sally Ceria (Sour Sally) adalah pionir yoghurt beku lokal yang dibuat dari bahanbahan dairy alami dan disajikan dengan berbagai pilihan saus dan toping. Sour Sally sudah berusia 10 tahun karena merek ini sudah berdiri sejak 15 Mei 2008. Ide awal mula bisnis ini berasal Donny Pramono (CEO \& Founder Sour Sally). Ketika kuliah di Los Angeles, ia sering mengunjungi outlet frozen yoghurt.

Dari situlah ide berbisnis terlintas dipikiran Donny Pramono untuk membuat usaha frozen yoghurt di Indonesia. Akhirnya Donny Pramono memilih bekerja di perusahaan frozen yoghurt di Amerika. Setelah itu, Donny Pramono kembali ke Indonesia dan mempersiapkan usaha yoghurt yang diberi nama Sour Sally.

Tepat di tahun 2008, outlet pertama Sour Sally di Senayan City Mall. Saat ini Sour Sally telah berkembang dengan 35 outlet tersebar di Jakarta, Bandung, Medan, Bali, Semarang, Makassar, dan lainnya.

Pada tahun 2015, Sour Sally memutuskan melakukan rejuvenation (peremajaan merek) agar Sour Sally dikonsumsi berbagai kalangan. Sour Sally merubah (rebranding) semua aspek tanpa menghilangkan identitas Sour Sally.

Peneliti membahas alasan Sour Sally melakukan rejuvenation. Alasan dari peremajaan merek adalah untuk memperluas target market Sour Sally yang awalnya terlalu fokus kepada wanita dan mengikis citra girlie karena konsep lama Sour Sally. 
p-ISSN: 0853-4470 - Vol. 02, No. 01 (2019), pp. 19-26

Tantangan saat itu adalah apabila Sour Sally tidak merejuvenate semuanya maka konsumen hanya melihat Sour Sally mengeluarkan produk baru, tidak ada yang menarik karena hanya inovasi produk dengan pemikiran publik yang lama girlie. Oleh sebab itu, Sour Sally melakukan peremajaan semua aspek merek Sour Sally (Gambar 1) tanpa menghilangkan identitas Sour Sally sehingga memperkuat citra fresh dan healthy yoghurt.

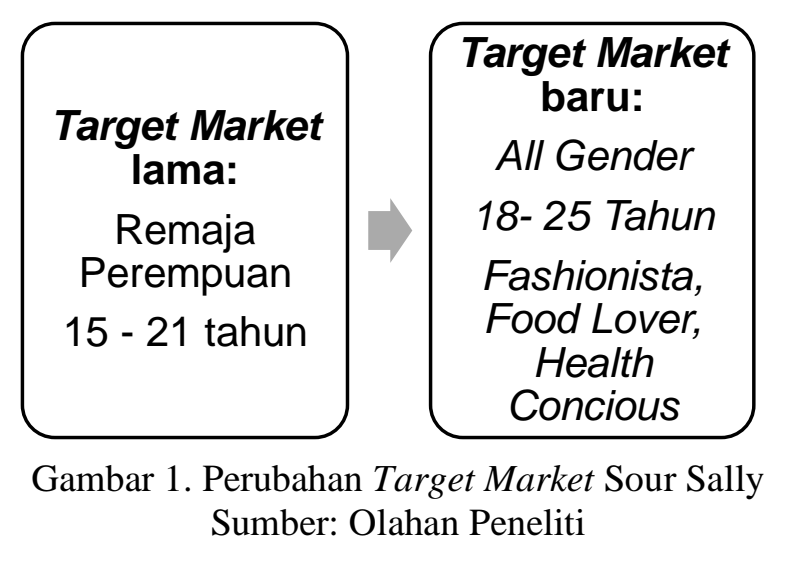

Setiap perusahaan pasti menginginkan citra yang baik di mata publiknya. Citra Sour Sally yang terkesan girlie ingin dibuah secara universal. Oleh karena itu, Sour Sally memiliki wish image memiliki citra dessert yang sehat dan enak dan agar menarik kembali pelanggannya yang dilakukan dengan melakukan hal-hal berikut ini:

Publikasi. Menurut Kotler \& Keller (2009: 595), perusahaan menggunakan publikasi untuk mempengaruhi target market. Kegiatan publikasi yang dilakukan Sour Sally adalah media online yaitu media sosial Instagram @ soursallycoid, mengembangkan Influencer, Food Buzzer, Instagram Ads, Official Website, Media Internal, Press Release, bekerjasama dengan partner pihak ketiga.

Dampak publikasi yaitu upaya untuk promosi yang efektif dan efisien mengingat semakin meningkatnya biaya promosi di media massa secara komersial (Ruslan, 2016, Saraswati, 2018). Selain itu dapat untuk meningkatkan engagement reach dan immediate response dari public (Evelina, 2018; Rachmawati, 2018; Hutagalung, 2018) .

Kendala yang dialaminya yaitu penyesuaian perubahan targeting ke customer Sour Sally saat ini. Walaupun demikian, Sour Sally mampu menangani tantangan tersebut dan terus mengembangkan inovasi strategi publikasinya. Sampai saat ini, Sour Sally aktif membuat konten di Instagram. Jadi dapat disimpulkan bahwa strategi publikasi Sour Sally berfokus pada online karena lebih hemat biaya, terarah, serta sesuai dengan target market Sour Sally.

Acara. Alat Marketing Public Relations yang kedua ialah acara. Kotler dan Keller (2009: 595) menyebutkan bahwa perusahaan dapat menarik perhatian publik mengenai produk baru atau aktivitas perusahaan dengan mengadakan acara. Dalam temuan penelitian ini, pelaksanaan event dibagi menjadi dua yaitu offline event dan juga online event. Beberapa acara yang pernah diselenggarakan oleh Sour Sally yaitu Press Conference.

Sour Sally juga sering menyelenggarakan event launching yang dibagi menjadi dua yakni major launching (produk yoghurt) dan minor launching (produk non-yoghurt atau toppings). CEO dan Founder Sour Sally turut aktif dalam mengembangkan alat event launching agar publik mengetahui dengan produk yang baru diluncurkan, contohnya major product adalah saat Grand Launching "All New Sour Sally" dengan produk Black Sakura dan contoh launching minor product adalah launching baru Sour Sally topping buah baru, Cultured Club. Selain itu, Sour Sally aktif mengikuti bazaar-bazaar di pusat perbelanjaan.

Selain offline event, Sour Sally juga memiliki online event. Contoh online event yang diselenggarakan Sour Sally adalah online campaign via Instagram. Dalam $P R$, kampanye adalah hal yang sering dilakukan oleh praktisi $P R$. Sama seperti offline event, umumnya dalam satu tahun Brand Manager Sour Sally memiliki target satu major campaign dan dua minor campaign dari owner. 
Beberapa kampanye yang pernah dibuat oleh Sour Sally adalah Handfie Campaign, Gue Rela Antri Campaign, Cakep Cakep Belepotan Campaign, Gold Digger Challenge Campaign, dan lainnya. Selain acara eksternal, Sour Sally aktif mengadakan internal event perusahaan. Tujuan dari acara Internal adalah untuk menjaga dan mempererat kekeluargaan sesama karyawan dan managemen perusahaan seperti Gathering. Dampak dari keaktifan Sour Sally menyelenggarakan event tentunya meningkatkan awareness.

Sour Sally berupaya untuk mengedukasi customer produk dessert yang sehat. Kendala yang paling sering dialami acara Sour Sally adalah partisipan kampanye (campaign atau competition) padahal hadiah yang ditawarkan cukup menarik. Sour Sally mengatasinya dengan cara memasang Instagram $A d s$ secara berkala agar pesannya dapat tersampaikan.

Sponsor. Menurut Kotler \& Keller (2009: 595), perusahaan dapat mempromosikan merek dan perusahaan mereka dengan memberikan sponsor acara-acara olahraga, budaya atau acara lainnya. Pemberian sponsor yang diberikan oleh Sour Sally berbentuk produk yoghurt. Salah satu kegiatan olahraga yang pernah disponsori oleh Sour Sally adalah acara golf tahunan.

Sour Sally juga sering memberikan sponsor produk pada acara seminar, acara sekolah/universitas. Sour Sally juga pernah memberikan sponsor untuk acara Pekan Produk Kreatif Indonesia oleh Badan Ekonomi Kreatif. Pemberian sponsor dapat mempererat hubungan dengan organisasi lain dan memperluas market Sour Sally yang belum terjangkau oleh Sour Sally.

Kendala Sponsor yang dialami oleh Sour Sally sering dihadapi adalah terbatasnya frekuensi sponsor dan bentuk sponsor. Tidak seperti beberapa perusahaan lainnya, Sour Sally mengaku belum memiliki prioritas utama dan belum menjalankan program sponsor secara teratur.

Berita. Kotler dan Keller (2009: 595) mengatakan, tugas utama seorang Public Relations (PR) adalah untuk membuat berita tentang perusahaan, produknya, dan orang-orang dalam perusahaan tersebut. Pasca rejuvenation. Sour Sally mengaku terbuka dengan pemberitaan media, justru berita sangat diinginkan karena tokoh, produk dan pesan dapat tersampaikan lebih kredibel melalui media. Beberapa media yang pernah meliput Sour Sally baik online, cetak ataupun TV.

Dampaknya membina hubungan baik dengan kalangan pers berita adalah, awareness meningkat sehingga dapat menggiring jumlah pengunjung ke toko. Pentingnya bekerjasama dengan media dan wartawan untuk memperluas market yang belum terjangkau. Kendala yang dihadapi adalah perbedaan news value yang ingin disampaikan dari pihak perusahaan dengan media, berita yang dimuat tidak sepenuhnya sesuai dengan keinginan perusahaan.

Pidato. Sour Sally pernah menjadi pengisi acara baik guest speaker atau tuan rumah untuk memberikan pidato. Selain pidato, $C E O \&$ Founder Sour Sally sering diundang untuk menjadi guest speaker di sebuah acara untuk berbagi cerita entrepreneurship. Tujuan dari pidato dapat menyampaikan visi, misi dan exposure tentang perusahaan, menjadikan citra Sour Sally lebih positif karena sebagai role model semangat entrepreneurship dan brand yang sukses ditengah persaingan. Oleh karena itu, pentingnya membangun kredibilitas perusahaan melalui pidato.

Kegiatan Layanan Masyarakat (CSR). Kegiatan pelayanan masyarkat yang pernah dilakukan oleh Sour Sally adalah mengadakan program "Smile for Smile" bekerjasama dengan Yayasan Kasih Anak Kanker Indonesia (YKAKI). Kampanye CSR Sour Sally "Cakep Cakep Belepotan" berlangsung selama hampir lima bulan bulan ( Desember 2015 - 30 April 2016) mengangkat produk Black Sakura sebagai tema besar dari program CSR ini. Sour Sally menyumbangkan bantuan sponsor kepada YKAKI dari hasil penyisihan Rp. 500 penjualan produk Black Sakura.

Dalam acara CSR Sour Sally, Sour Sally ingin melakukan kegiatan CSR yang berkaitan dengan product value yaitu Black Sakura terbuat dari 100\% charcoal dan bahan-bahan alami lainnya sehingga berwarna hitam. Bahan charcoal adalah salah satu zat detox yang bisa membantu mencegah penghantaran kanker. Oleh karena itu, Sour Sally ingin membuat program CSR yang berhubungan dengan produknya.

CSR ini adalah salah satu cara untuk membangun citra yang postiif dimata publik karena Sour Sally mengajak partisipasi konsumen dengan membeli Black Sakura, konsumen juga berdonasi untuk anak-anak YKAKI. Sour Sally tercatat hanya pernah menjalankan satu program CSR padahal sebelum 
rejuvenate Sour Sally sering mengadakan CSR. Kendala ini dikarenakan belum adanya titik terang sebuah program CSR dan masih berfokus dengan rejuvenation.

Media Identitas. Perusahaan membutuhkan identitas yang dapat secara langsung dikenal oleh publik secara cepat. Dalam rejuvenation ini, Sour Sally merubah seluruh aspek media identitasnya tanpa menghilangkan identitas Sour Sally. Media identitas yang berubah adalah logo, tagline, mascot Sally, pemilihan warna, produk, desain media promosi, atribut fisik (packaging, store), dan masih banyak lainnya.

Perubahan media identitas Sour Sally dirasakan secara langsung oleh publik mendapatkan respon yang sangat positif, lebih menyukai media identitas yang saat ini. Perubahan media identitas ini menjadi salah satu upaya untuk merubah citra girlie yang melekat pada Sour Sally.

Kendalanya yaitu saat media identitas warna hitam sebagai warna utama yang terkesan gelap dikhawatirkan tidak sesuai dengan produk makanan yang harusnya menggunakan warna terang. Namun ternyata, warna hitam tersebut dapat menjadi trendsetter bagi produk-produk $F \& B$ lainnya yang bermunculan selama beberapa tahun kemudian.

Hasil Rejuvenation dengan Citra dan Sales. Mendapat citra positif inovatif dan antusias sehingga menjadi loyal customer Sour Sally. Sour Sally optimis telah menjadi top of mind untuk frozen yoghurt di Indonesia. Pencapaian rejuvenation Sour Sally terbukti dengan penghargaan "Top Brand Award 2016" dalam kategori Frozen Yoghurt Asia dari Singapura.

Selain itu, Upaya Marketing Public Relations yang baik dapat meningkatkan sales dari perusahaan tersebut. Hasil penelitian menyebutkan, pada awal rejuvenation, sales Sour Sally dapat mencapai tujuh kali lipat. Walaupun saat ini tidak setinggi dari awal, namun penurunannya kecil dan tetap masih signifikan meningkat. Keadaan sales ini tentunya berbeda dengan sebelum rejuvenation.

Hasil Rejuvenation dengan Loyal Customer. Alat Marketing Public Relations yaitu publikasi, dapat menjadi alat yang paling tepat untuk mengkomunikasikan "All New Sour Sally”. Narasumber eksternal setuju bahwa citra yang digambarkan Sour Sally mengarah ke girlie, sedangkan citra yang diinginkan saat ini adalah healthy lifestyle dessert.

Dari seluruh narasumber eksternal yang diwawancaraI, semuanya yakin dan setuju bahwa mereka jauh lebih menyukai Sour Sally dengan citra baru “All New Sour Sally” karena lebih menarik dan berinovasi. Dari semua perubahan Sour Sally, perubahan terbaik dari Sour Sally yang membedakan dari kompetitornya.

Ketujuh alat MPR menurut Kotler \& Keller (2009) dijalankan dengan baik seiring dengan rejuvenation All New Sour Sally. Publikasi dan Acara menjadi alat MPR utama yang dikerjakan oleh Marketing Public Relations Sour Sally.

dengan usaha ini, Sour Sally berupaya untuk membangun citra All New Sour Sally. Sesuai dengan Ishaq (2017) ada beberapa faktor yang membentuk citra yaitu identitas, manajemen organisasi, pola komunikasi serta produk. Secara identitas fisik, Sour Sally mengubah media identitasnya yang lebih netral terutama pemilihan warna dan logo. Customer Sour Sally juga menyadari dan lebih menyukai perubahan identitas saat ini.

Dalam hal ini, manajemen positioning organisasi berubah karena Sour Sally merubah target market. Secara pola komunikasi, Sour Sally juga memperbaharui pola komunikasi untuk menyampaikan pesan healthy frozen yoghurt yang tersampaikan dengan baik kepada customer. Terakhir yaitu kualitas produk dan layanan yang tercitra inovatif dan orisinil dengan produk Black Sakura pertama di dunia yang menjadi faktor pembentuk citra suatu organisasi atau perusahaan.

\section{KESIMPULAN}

Dalam upaya rejuvenation untuk mengikis citra girlie dan memperluas pasar, Sour Sally melakukan rejuvenation. Hasil temuan peneliti menunjukkan Sour Sally menggunakan ketujuh alat Marketing Public Relations. Publikasi yaitu Social Media, Website, Partnership. Acara yaitu Major dan Minor Event/Campaign. Sponsor dan pidato dalam serangkaian acara. Sour Sally dimuat di beberapa media online, TV maupun cetak dan Smile for Smile adalah kegiatan CSR Sour Sally. Terakhir, Sour Sally mengubah media identitasnya seperti logo, tagline, warna, atribut lainnya untuk memberikan pesan healthy dessert melalui citra All New Sour Sally. 
p-ISSN: 0853-4470 - Vol. 02, No. 01 (2019), pp. 19-26

Citra All New Sour Sally yang dibangun oleh Sour Sally dengan menghilangkan citra girlie dapat dikatakan telah berhasil dan citra perubahan Sour Sally sebagai healthy frozen yoghurt tersampaikan kepada customer yang mencitrakan Sour Sally sebagai dessert sehat dan enak untuk semua orang. Oleh sebab itu, kegiatan Marketing Public Relations untuk membangun citra baru "All New Sour Sally” dapat disimpulkan berhasil dan memberikan dampak yang baik.

\section{Daftar Pustaka}

Ardelia, B. (2011, November 16). Brand Rejuvenation, Sekarang atau Nanti? Diperoleh dari Okezone: https://economy.okezone.com/read/-2011/11/16/23/530007/brand-rejuvenationsekarang-atau-nanti

Ardianto, E. (2014). Metodologi Penelitian untuk Public Relations: Kuantitatif dan Kualitatif. Bandung: Simbiosa Rekatama Media.

Ardianto, E. (2016). Handbook of Public Relations. Bandung: Simbiosa Rekatama Media.

Batey, M. (2016). Brand Meaning: Meaning, Myth and Mystique in Today's Brands. New York: Psycology Press.

Evelina, L.H., Fitri H. (2018). Penggunaan Digital Influencer dalam Promosi Produk (Studi Kasus Akun Instagram @bylizzieparra). Warta Ikatan Sarjana Komunikasi Indonesia, Vol. 1(1), 71-82.

Harris, T. L. (1991). The Marketer's Guide to Public Relations. New York: John Wiley \& Sons, Inc. Hutagalung, I. (2018). Ambassador Produk dan Perubahan Sikap (Studi Kasus Pengolahan Iklan Kosmetik XYZ Berdasarkan Pendekatan Teori ELM di Kalangan Remaja Putri Kelurahan Rawa Buaya, Jakarta Barat. Warta Ikatan Sarjana Komunikasi Indonesia, Vol. 1(1), 1-8.

Instagram. (2018, Mei 1). Instagram Sour Sally. Diperoleh dari website Instagram Sour Sally: www.instagram.com/soursallycoid

Ishaq, R. E. (2017). Public Relations: Teori \& Praktik. Malang: Intrans Publishing.

Jefkins, F. (2002). Public Relations disi Kelima. Jakarta: Erlangga.

Kotler, P., \& Keller, K. L. (2009). Marketing Management: an Asian Perspective. Singapore: Pearson Education.

Kriyantono, R. (2006). Teknik Praktis Riset Komunikasi. Jakarta: Kencana Prenada Media Group.

Kriyantono, R. (2014). Teori Public Relations Perspektif Barat \& Lokal: Aplikasi Penelitian dan Praktik. Jakarta: Prenadamedia Group.

Rachmawati, D, Dini S.F.A. (2018). Analisis Personal Branding Selegram Nonselebriti Akun Instragram @Lippielust. Warta Ikatan Sarjana Komunikasi Indonesia, Vol. 1(1), 34-40.

Ruslan, R. (2004). Metode Penelitian: Public Relations dan Komunikasi. Jakarta: Raja Grafindo Persada.

Ruslan, R. (2016). Manajemen Public Relations \& Media Komunikasi: Konsepsi dan Aplikasi. Jakarta: Rajawali Pers.

Rustan, S. (2009). Mendesain Logo . Jakarta: PT Gramedia Pustaka Utama.

Saraswati, M.S. (2018). Social Media and the Political Campaign Industry in Indonesia. Jurnal Komunikasi Ikatan Sarjana Komunikasi Indonesia, Vol. 3(1), 51-65.

Sally, S. (2018, Januari 15). "SOUR SALLY : FROZEN YOGHURT." Diperoleh dari website, Sour Sally: http://www.soursally.co.id/ dan Data Internal Perusahaan Marketing Communications

Soemirat, S., \& Ardianto, E. (2008). Dasar-Dasar Public Relations. Bandung: PT Remaja Rosdakarya.

Sugiyono. (2010). Memahami Penelitian Kualitatif. Bandung: Alfabeta.

Sugiyono. (2016). Metode Penelitian: Kuantitatif, Kualitatif dan R\&D. Bandung: Alfabeta.

The New Kontan Weekend. (2010). Mencicipi Laba Bisnis Yoghurt Beku. Diperoleh dari http://weeekend.kontan.co.id/index.php/peluang_usaha/post/6610/mencicipi-laba-bisnisyoghurt-beku. 